Vol. 2 No. 2 Desember 2019, hal $154-175$

\title{
KONSEP KECERDASAN MAJEMUK HOWARD GARDNER
}

\author{
Syarifah \\ IAIN Syaikh Abdurrahman Siddik Bangka Belitung \\ E-mail : Syarifahjunaidi@gmail.com
}

\begin{abstract}
The theory of Multiple Intelligences is revealed by Howard Gardner. In this theory, intelligence means the ability to solve problems or fashion products, that are valued in one or more cultural or community settings. This theory indicated that everyone has nine intelligences: linguistic, logical-mathematical, spatial, bodily-kinesthetic, musical, interpersonal, intrapersonal, naturalist, and existential. The multiple intelligences development can be done with educational methods included Islamic educational methods. This matter is done to establish the happy and humanist Islamic education process and to maximize child's multiple intelligences.
\end{abstract}

Keywords: Multiple intelligences, theory, development, Howard Gardner

\begin{abstract}
ABSTRAK
Teori Multiple Intelligences diungkapkan oleh Howard Gardner. Dalam teori ini, kecerdasan berarti kemampuan untuk menyelesaikan masalah atau produk fesyen, yang dinilai dalam satu atau lebih pengaturan budaya atau komunitas. Teori ini menunjukkan bahwa setiap orang memiliki sembilan kecerdasan: linguistik, logismatematis, spasial, kinestetik-tubuh, musik, antarpribadi, intrapersonal, naturalis, dan eksistensial. Pengembangan kecerdasan ganda dapat dilakukan dengan metode pendidikan termasuk metode pendidikan Islam. Hal ini dilakukan untuk membangun proses pendidikan Islam yang humanis dan bahagia serta memaksimalkan kecerdasan ganda anak.
\end{abstract}

Kata Kunci : Multiple intelligences, Teori, Pengembangan, Howard Gardner

\section{Pendahuluan}

Berbicara tentang kecerdasan, yang pertama kali terlintas di benak kita tentulah berkenaan dengan kemampuan kognisi seseorang. Kecerdasan atau inteligensi memang sering diartikan sebagai kemampuan memahami sesuatu dan kemampuan berpendapat, di mana semakin cerdas seseorang maka semakin cepat ia memahami suatu permasalahan dan semakin cepat pula mengambil langkah penyelesaian terhadap permasalahan tersebut (Mustaqim 2004: 104). Dalam hal ini, kecerdasan dipahami sebagai kemampuan intelektual yang lebih menekankan logika dalam memecahkan masalah. Kecerdasan seseorang biasanya 
diukur melalui tes Intelligence Quotient (IQ) (Abdul Mujib dan Jusuf Mudzakir 2002: 319). Jadi, kecerdasan hanya dipandang dari kemampuan seseorang dalam menyelesaikan ujian dalam bentuk soal-soal yang merupakan tes standar di ruang kelas.

Menurut Thomas R. Hoerr (2007: 9-10), tes tersebut hanya mengukur kecerdasan secara sempit karena hanya menekankan pada kecerdasan linguistik dan matematis-logis (akademis). Walaupun tes standar yang terfokus pada kecerdasan akademis tersebut dapat memperkirakan keberhasilan anak di sekolah, namun tidak bisa memperkirakan keberhasilan seseorang di dunia nyata, karena keberhasilan di dunia nyata saat ini mencakup lebih dari sekedar kecakapan linguistik dan matematis-logis. Dengan demikian, ada kecerdasan lain yang mempunyai pengaruh lebih besar terhadap keberhasilan seseorang. Hal ini mendorong para ahli psikologi untuk melakukan penelitian lebih lanjut yang akhirnya menemukan dua kecerdasan lain di samping kecerdasan intelektual, yaitu kecerdasan emosional (EQ) dan kecerdasan spiritual (SQ).

Anggapan berlebihan terhadap kemampuan IQ dalam menentukan keberhasilan seseorang nampaknya masih mendominasi pembelajaran dan pendidikan di sekolah. Salah satunya nampak dari metode yang digunakan para guru ketika menyampaikan pelajaran. Menurut Paul Suparno (2008: 6), guru seringkali mengajar dengan pendekatan yang rasional dengan logika-matematika yang lebih sesuai dengan kecerdasan matematis-logis dan menjelaskan semua pelajaran dengan model ceramah dan cerita yang lebih sesuai dengan kecerdasan linguistik. Metode pembelajaran seperti ini hanya menguntungkan bagi anak-anak yang memiliki kecerdasan matematis-logis dan linguistik saja, sementara siswa yang tidak memiliki kecerdasan-kecerdasan tersebut cenderung merasa bosan, tidak mengerti, terasing, dan merasa tidak pernah diperhatikan serta diajar di sekolah oleh gurunya. Hal ini menurut Abdul Munir Mulkhan (2002: 80) karena model pembelajaran di sekolah yang menyimpang dan melanggar nilai-nilai dasar kemanusiaan bagi setiap siswa, salah satunya adalah penggunaan metode pembelajaran yang tidak sesuai dengan kecerdasan yang menonjol pada siswa. 


\section{PEMBAHASAN}

\section{A. Biografi dan Aktivitas Intelektual Howard Gardner}

Sebelum berbicara lebih lanjut mengenai teori kecerdasan majemuk, tentunya perlu juga mengenal siapa sebenarnya pencetus teori yang menyita banyak perhatian berbagai kalangan tersebut. Adapun pencetus pertama teori kecerdasan majemuk adalah Gardner.

Gardner, nama lengkapnya Howard Gardner, adalah seorang psikolog perkembangan dan ahli pendidikan. Dia lahir pada tanggal 11 Juli 1943 dan dibesarkan di Scranton, sebuah kota ukuran menengah/sedang bekas pertambangan batubara di Timur Laut Pennsylvania, Amerika Serikat (Ladislaus Naisaban 2004: 158-162 ). Kedua orang tuanya, Ralph dan Hilde Gardner, termasuk pengungsi yang melarikan diri dari kekejaman Nazi Jerman dan kemudian menetap di Amerika Serikat pada tanggal 9 November 1938. Orang tuanya kehilangan anak pertama mereka yang saat itu berumur delapan tahun akibat kecelakaan kereta luncur. Anak tersebut adalah Eric, kakak Gardner yang saat itu meninggal menjelang kelahiran Gardner. Kejadian tersebut nampaknya telah menimbulkan semacam trauma bagi orang tua Gardner. Hal ini nampak dari sikap yang ditunjukkan orang tuanya terhadap Gardner kecil. Gardner selalu dilarang melakukan aktivitas yang dapat membahayakan fisiknya, seperti bersepeda dan olahraga berat lainnya, sehingga kegemarannya pada musik, menulis, dan membacalah yang kemudian dikembangkan. Bahkan musik menjadi hal yang penting dalam hidupnya.

Walaupun semua kejadian buruk yang menimpa keluarganya tidak pernah diceritakan kepada Gardner kecil, namun Gardner sendiri yang akhirnya menemukan bahwa mereka adalah keturunan Yahudi yang dikejarkejar Nazi (Ladislaus Naisaban 2004: 158). Baginya, kejadian-kejadian tersebut tetap berpengaruh besar terhadap perkembangan dan pemikirannya. Kejadian tersebut bahkan telah menjadikannya dewasa dan memahami bahwa sebagai anak sulung yang masih hidup dalam keluarga besarnya, ia dituntut berbuat banyak di negara baru (Amerika Serikat). Dia juga menyadari bahwa para pemikir keturunan Yahudi dari Jerman dan Austria seperti Einstein, 
Freud, Marx, dan Mahler, hidup dan telah belajar serta bersaing dengan pemikir-pemikir lainnya di pusat-pusat intelektual Eropa, sementara dia sendiri terkungkung di lembah Pennsylvania yang tidak menarik. Akibatnya, ia mengalami kebuntuan intelektual serta depresi ekonomi.

Keinginan yang kuat untuk maju dan berkembang serta kegandrungannya terhadap musik menyebabkan dia menolak keinginan orangtuanya untuk menyekolahkannya di Philips Academy di Massachusetts, dia bahkan pergi sekolah ke Wyoming Seminary di Kingston (Ladislaus Naisaban 2004: 158).

Setelah menyelesaikan studinya di sekolah tersebut, pada tahun 1961 dia melanjutkan studinya ke Harvard University, tempat di mana sekarang dia mengabdikan diri. Di universitas tersebut dia mempelajari sejarah sebagai persiapan untuk karier di bidang hukum, khususnya pengacara. Selain itu, dia juga banyak belajar tentang sosiologi dan psikologi. Di universitas itu juga dia bertemu dengan orang-orang yang banyak memberinya inspirasi untuk membuat penelitian khusus tentang hukum alam manusia, mereka adalah pakar psikoanalisis Eric Erikson (orang yang telah memperkuat ambisinya untuk menjadi seorang akademikus), sosiolog David Riesman, dan psikolog kognisi Jerome Bruner (Ladislaus Naisaban 2004: 158)

Pada tahun 1965 Gardner berhasil memperoleh gelar A.B. dengan summa cum laude dalam bidang psikologi dan ilmu pengetahuan sosial. Dari sini dia bekerja bersama Jerome Bruner dalam MACOS Project. Dalam perjalanan kariernya di proyek tersebut, dia banyak membaca karya-karya Claude Levi-Strauss dan Jean Piaget, bahkan bangkitnya minat Gardner untuk menyelidiki lebih lanjut mengenai "perkembangan" juga terinspirasi dari karya Jean Piaget mengenai tahap perkembangan kognisi manusia. Namun menurut Gardner, konsep Jean Piaget tentang perkembangan kognisi manusia terutama konsepsi anak sebagai "bakal ilmuwan” tidak lagi memadai untuk zaman sekarang (Ladislaus Naisaban 2004: 159)

Bagi Gardner, sebagaimana dikutip oleh Joy A. Palmer (2006: 484), bahwa orang-orang yang ahli dalam bidang-bidang lain, seperti pelukis, penulis, musikus, penari, dan seniman lainnya juga memiliki kemampuan 
kognitif yang tinggi. Oleh karena itu, apa yang disebut dengan "berkembang" perlu memperhatikan hal-hal tersebut.

Pada tahun 1966, Gardner melanjutkan program doktornya di Harvard University dan selesai pada tahun 1971. Selama di Harvard University dia dilatih menjadi seorang psikolog perkembangan kemudian menjadi seorang neurolog. Berdasarkan hasil penggodokan dari berbagai institusi tempat dia menuntut ilmu terutama di Universitas Harvard, akhirnya dia menjadi seorang ahli dalam bidang psikologi, neurologi, bahkan pendidikan. Setelah menempuh perjalanan yang begitu panjang, akhirnya saat ini dia telah menjadi seorang profesor yang khusus mendalami kognisi dan pendidikan di Departemen Pendidikan Harvard University, profesor psikologi di Harvard University, profesor Neurologi di Sekolah Kedokteran Universitas Boston, dan ketua tim (direktur) senior Proyek Zero (Joy A. Palmer 2006: 484). Ketika melakukan berbagai kegiatan penelitian di proyek itulah Gardner menemukan teori Multiple Intelligences.

Multiple Intelligences adalah istilah yang digunakan oleh Howard Garner untuk menunjukkan bahwa pada dasarnya manusia itu memiliki banyak kecerdasan. Teori ini kemudian dikembangkan dan diperkenalkan pada tahun 1983 dalam bukunya yang berjudul Frames of Mind, yang telah diterjemahkan ke dalam dua belas bahasa. Selanjutnya pada tahun 1993 dia mempublikasikan bukunya yang berjudul Multiple Intelligences: The Theory in Practice, sebagai penyempurnaan atas buku yang terbit sebelumnya, setelah banyak melakukan penelitian tentang implikasi sekaligus aplikasi teori kecerdasan majemuk di dunia pendidikan di Amerika Serikat. Teori tersebut disempurnakan lagi dengan terbitnya buku Intelligence Reframed pada tahun 2000 (Paul Suparno 2008: 17). Bahkan wacana mengenai Multiple Intelligences diperluas kembali di dalam bukunya Multiple Intelligences: New Horizons yang terbit pada tahun 2007.

Sebagai seorang pakar yang banyak melakukan penelitian dan menyenangi bidang seni, maka di Universitas Harvard, Gardner dipercayakan untuk memberikan banyak mata kuliah, antara lain: mengenai inteligensi, kreativitas, kepemimpinan, tanggung jawab profesional, kegiatan ilmiah antar 
disiplin ilmu, manajemen kerja yang baik, dan seni (Ladislaus Naisaban 2004: 159).

Seperti telah dijelaskan bahwa Gardner adalah seorang yang aktif dalam bidang penelitian sekaligus ahli dalam bidang musik dan psikologi. Oleh karena itu, tidak mengherankan jika dia banyak menyandang atau menduduki berbagai jabatan (Ladislaus Naisaban 2004: 159). Dari beberapa jabatan yang disandang Gardner sejak tahun 1958 sampai sekarang, mengindikasikan bahwa dia adalah orang yang aktif, penting, dan berpengaruh di dunia psikologi. Sebagai seorang psikolog dan ahli pendidikan yang cukup berpengaruh di dunia, terutama di Amerika Serikat, serta banyaknya melakukan penelitian ataupun kegiatan-kegiatan lainnya yang didukung oleh semangat untuk terus berkembang, dia banyak mendapatkan penghargaan dalam berbagai bidang. Bahkan pada tahun 2004, Garner mendapat gelar sebagai Profesor Honorary di East China Normal University di Shanghai dan pada tahun 2005 beliau terpilih oleh polis (kebijakan) luar negeri dan majalah "Prospect" sebagai salah satu dari seratus kalangan intelektual yang paling berpengaruh di dunia.

\section{B. Latar Belakang Munculnya Teori Kecerdasan Majemuk}

Menurut Agus Efendi (2005: 136-137), ketika mengantarkan edisi ke10 dari Frames of Mind (1983), Gardner menegaskan bahwa sembari menulis Frames of Mind, ia memandang karya tersebut sebagai kontribusinya terhadap disiplin psikologi perkembangan yang digelutinya. Dengan karya tersebut, Gardner hendak memperluas konsepsi kecerdasan, dari hanya menyangkut the result of paper and pencil test, menjadi pengertian yang lebih luas yang menyangkut pengetahuan tentang otak manusia dan kepekaannya terhadap ragam budayanya (sensitivity to the diversity of human cultures).

Namun demikian, terbitnya buku tersebut, menurut Joy A. Palmer (2006: 482-483), justru menempatkan dia dalam percaturan teori dan praktik pendidikan di Amerika Serikat serta membuatnya terkenal di seluruh dunia. Oleh karena mendapat sambutan dari dunia pendidikan, bahkan menurut Agus Efendi (2005: 137), dalam karya selanjutnya mengenai kecerdasan 
majemuk, seperti Multiple Intelligences: The Theory in Practice, Multiple Intelligences: New Horison, dan sebagainya, Gardner banyak memasukkan wacana-wacana pendidikan kontemporer. Karya-karya sesudah Frames of Mind, lebih dijadikan sebagai penyerta dan penyempurnaan bagi karya tersebut.

Terlepas dari itu semua, dalam bukunya Frames of Mind, Gardner (1973) menjelaskan empat hal terkait dengan latar belakang munculnya teori kecerdasan majemuk, yaitu The Idea of Multiple Intelligences (ide mengenai kecerdasan majemuk), Intelligences: Earlier Views (pandangan awal mengenai kecerdasan), Biological Foundations of Intelligences (fondasi biologis kecerdasan), dan What is an Intelligence? (apa itu kecerdasan?).

Dalam bidang tes kecerdasan, perdebatan terjadi antara orang-orang yang mengikuti Charles Spearmen yang meyakini faktor umum intelektual dan orang-orang yang mengikuti L. L. Thurstone yang meyakini keragaman kemampuan mental. Menurut Gardner (1973), perdebatan tentang pembagian kecerdasan ke dalam bagian-bagian masih terus berlangsung dan belum menunjukkan adanya tanda-tanda penyelesaian. Bahkan Gardner sendiri menyangsikan bahwa topik-topik seperti kehendak bebas atau konflik antara keyakinan dan alasan akan ditetapkan untuk kepuasaan seseorang.

Oleh karena itu, dalam kesimpulannya, Gardner (1973: 8-9) menunjukkan adanya bukti persuasif mengenai eksistensi atau adanya kompetensi intelektual manusia yang otonom secara relatif, yang selanjutnya disebut dengan "kecerdasan manusia." Inilah yang oleh Gardner disebut dengan "Frames of Mind" (seperti judul buku teori kecerdasan majemuk). Sifat pasti dan keluasan masing-masing "kerangka" intelektual, sejauh ini belum ada ketetapan yang memuaskan serta belum ada kepastian mengenai jumlah kecerdasan itu sendiri. Namun, diyakini bahwa minimal ada beberapa jenis kecerdasan yang relatif independen satu sama lain dan bisa dibentuk serta dikombinasikan dalam sebuah keragaman cara-cara adaptif oleh individuindividu atau budaya-budaya, dan nampaknya bagi Gardner akan terus meningkat dan sulit untuk disangkal, jelasnya lebih lanjut. 
Kemudian, menurut Gardner (1973: 9), upaya-upaya sebelumnya untuk mendirikan kecerdasan-kecerdasan secara independen tidak begitu meyakinkan, terutama karena upaya-upaya tersebut hanya bersandar pada satu atau paling banyak dua bukti. Terpisahnya "pikiran" atau "kemampuan" diusulkan sebagai fakta semata-mata hanya berdasarkan atas analisis logis, disiplin pendidikan sejarah, hasil tes inteligensi, atau semata-mata atas dasar pengertian yang mendalam yang diperoleh dari studi tentang otak. Upayaupaya kecil ini jarang menghasilkan daftar kompetensi yang sama. Dengan demikian, jika dibuat untuk mengklaim kecerdasan majemuk nampaknya kurang bisa dipertahankan.

Kemunculan teori kecerdasan majemuk ini merupakan sebagai bentuk kegelisahan Howard Gardner dan para koleganya. Mereka menganggap bahwa teori-teori tentang kecerdasan yang muncul sebelum teori ini dikeluarkan tidak lagi memadai untuk saat ini. Oleh karena itu, perlu adanya teori baru yang sekiranya lebih relevan sesuai dengan konteks saat ini, akhirnya muncullah teori kecerdasan majemuk atau The Theory of Mutiple Intelligences.

\section{Macam-Macam Kecerdasan Majemuk}

Sebagaimana dijelaskan di atas, teori kecerdasan majemuk memandang bahwa manusia itu pada dasarnya memiliki banyak kecerdasan dan memiliki kemampuan untuk mengembangkan kecerdasan-kecerdasan tersebut sampai batas maksimal bila berada pada lingkungan yang mendukung.

Adapun kecerdasan yang dimiliki oleh manusia itu, menurut teori kecerdasan majemuk, ada sembilan macam dan semuanya memenuhi kriteria yang telah ditetapkan. Sembilan kecerdasan tersebut yaitu:

1. Kecerdasan Linguistik (Linguistic Intelligence)

Menurut teori kecerdasan majemuk, seperti yang diungkapkan oleh Thomas Armstrong (2005: 19), kecerdasan linguistik atau word smart adalah suatu kemampuan menggunakan kata-kata secara efektif. Dalam kegiatan pembelajaran di sekolah, menurut Thomas Armstrong, memperlihatkan bahwa kecerdasan linguistik ini mencakup sedikitnya dua pertiga bagian dari interaksi belajar-mengajar yang mencakup kegiatan 
membaca dan menulis. Dalam dua kegiatan tersebut (membaca dan menulis), terdapat cakupan luas kemampuan linguistik karena termasuk di dalamnya mengeja, kosakata, dan tata bahasa. Selain itu, kecerdasan linguistik juga berkaitan dengan kemampuan berbicara. Dalam hal ini, kecerdasan linguistik nampak pada para orator, pelawak, selebriti radio, atau politisi yang sering menggunakan kata-kata untuk memanipulasi dan mempengaruhi.

Berbeda dengan kecerdasan-kecerdasan yang lain, menurut Julia Jasmine (2007: 16-18), kecerdasan ini merupakan kecerdasan yang paling unik dan memiliki kaitan yang paling erat dengan kehidupan setiap orang. Hal ini dapat dipahami karena setiap orang yang mampu bertutur dan berkata-kata pada dasarnya bisa dikatakan memiliki kecerdasan tersebut dalam beberapa level. Namun demikian, orang yang memiliki kecerdasan linguistik ini sebenarnya tidak hanya sebatas mampu bertutur dan berkata-kata serta mampu mengkhidmati kata-kata pada tataran makna tersurat dan tersiratnya saja, namun juga mampu mengkhidmati bentuk dan bunyinya serta untuk citra yang tercipta ketika kata-kata dirancangreka dalam cara yang lain dan berbeda dari biasanya.

Kecerdasan linguistik menurut Thomas Armstrong (2002: 20-21) mencakup kemampuan dalam bidang fonologi, sintaksis, semantik, dan pragmatika. Oleh karena kecerdasan ini berkaitan erat dengan penggunaan bahasa, maka menurut Thomas Armstrong, simbol yang bisa digunakan untuk memahami kecerdasan ini adalah bahasa fonetis, misalnya bahasa Indonesia, bahasa Inggris, bahasa Arab.

Berdasarkan uraian di atas, dapat dipahami bahwa komponen inti dari kecerdasan linguistik adalah kepekaan terhadap bunyi, struktur, makna, fungsi kata dan kalimat, serta bahasa.

Adapun contoh orang-orang yang memiliki kecerdasan ini antara lain adalah para jurnalis, penulis, penyair sufistik, maupun orator (Agus Effendi 2005: 142). Contohnya, cerpenis sekaligus novelis Asma Nadia, Sutan Takdir Ali Syahbana, Marah Rusli, Habiburrahman El-Syirazi, penyair sufistik Jalaluddin Rummi, Emha Ainun Najib, Taufik Ismail, orator 
mantan presiden Republik Indonesia Soekarno. Mereka semua adalah orang-orang yang bisa dipandang memiliki kecerdasan linguistik yang mampu mempengaruhi orang lain.

Yang perlu diperhatikan dalam kecerdasan ini, menurut Gardner sebagaimana dikutip Thomas Armstrong (2002: 6) adalah bahwa ada banyak cara untuk mengungkapkan kecerdasan ini dalam kehidupan anak. Bisa jadi anak sangat menikmati menulis puisi, namun tidak pandai mengungkapkannya di depan kelas atau anak sangat pandai bercerita namun kesulitan ketika membaca. Oleh karena itu, dalam mengembangkan kecerdasan tersebut pada anak harus selalu memperhatikan arah kecenderungan anak saat memperlihatkan kecerdasan linguistik mereka.

2. Kecerdasan Matematis-Logis (Logical-Matematical Intelligence)

Dalam mengawali penjelasannya mengenai kecerdasan matematislogis ini, dalam bukunya Multiple Intelligences: The Theory in Practice, Gardner (2003) mengemukakan sebuah anekdot. Dari anekdot tersebut, menurut Howard Gardner, ada dua fakta penting mengenai kecerdasan logika-matematika. Pertama, dalam diri orang berbakat, proses dari penyelesaian masalah sering berlangsung amat cepat. Kedua, penyelesaian masalah dapat disusun sebelum penyelesaian itu diutarakan.

Menurut Gardner, sebagaimana dikutip oleh Paul Suparno (2008: 29), kecerdasan matematis-logis, yang oleh Thomas Armstrong dinamakan number smart (2005) atau logic smart (2002), adalah kemampuan yang lebih berkaitan dengan penggunaan bilangan dan logika secara efektif, seperti yang dimiliki oleh matematikus, saintis, programer, dan logikus. Termasuk dalam kecerdasan ini adalah kepekaan pada pola logika, abstraksi, kategorisasi, dan perhitungan. Dengan kata lain, menurut Agus Efendi (2005: 143), kemampuan dalam memahami hubungan-hubungan humanikal.

Orang yang memiliki kecerdasan matematis-logis ini, menurut Paul Suparno (2008: 29), sangat mudah membuat klasifikasi dan kategorisasi dalam pemikiran serta cara mereka bekerja. Dalam menghadapi banyak persoalan, orang yang memiliki kecerdasan ini akan mencoba untuk 
mengelompokkannya sehingga mudah dilihat mana yang pokok dan yang tidak, mana yang berkaitan antara satu dan yang lain, serta mana yang merupakan persoalan lepas. Mereka juga dengan mudah membuat abstraksi dari suatu persoalan yang luas dan bermacam-macam sehingga dapat melihat inti persoalan yang dihadapi dengan jelas. Selain itu, mereka juga suka dengan simbolisasi, termasuk simbolisasi matematis dan bahasabahasa komputer. Pola pemikiran orang seperti ini, menurut Paul Suparno, biasanya induktif dan deduktif. Jalan pikirannya bernalar dan dengan mudah mengembangkan pola sebab akibat.

Dari penjelasan di atas, sebagaimana diungkapkan juga oleh Thomas Armstrong (2002: 10), komponen inti dari kecerdasan matematislogis adalah kepekaan pada pola-pola logis atau numeris dan kapasitas mencernanya, serta kemampuan mengolah alur pemikiran yang panjang. Sedangkan sistem simbol yang digunakan adalah bahasa-bahasa komputer.

Adapun orang-orang yang dipandang memiliki kecerdasan matematis-logis yang tinggi antara lain, Einstein (ahli fisika), John Dewey (ahli pendidikan), Stepen Hawking (ahli fisika), dan Habibie (ahli pesawat terbang dan mantan presiden Indonesia) (Paul Suparno 2008: 30). Sementara itu, terkait dengan anak-anak di sekolah, Paul Suparno (2008: 30) mengungkapkan bahwa anak yang mempunyai kecerdasan matematislogis yang tinggi biasanya menonjol dalam bidang matematika, jalan pikirannya logis dan rasional bila bicara dan memecahkan persoalan.

Dengan pernyataan yang lebih runtut Thomas Armstrong (2002: 26-27) menjelaskan bahwa anak-anak yang memiliki kelebihan dalam kecerdasan ini, sebelum memasuki masa remaja, biasanya suka menjelajahi pola, kategori, dan hubungan dengan secara aktif memanipulasi lingkungan serta bereksperimen dengan berbagai hal menggunakan cara-cara yang terkendali dan teratur.

\section{Kecerdasan Spasial/Ruang-Visual (Visual/Spatial Intelligence)}

Dalam menjelaskan tentang kecerdasan spasial atau picture smart, Thomas Armstrong (2002: 37-38) membuat sebuah ilustrasi. Dalam ilustrasi tersebut, Thomas Armstrong menekankan pada pentingnya 
kekuatan persepsi yang terfokus untuk mengungkapkan apa yang ada pada segala sesuatu yang tampak. Keadaan ini sangat erat kaitannya dengan kecerdasan spasial karena menyangkut kecerdasan dalam melihat.

Kecerdasan spasial, menurut Gardner sebagaimana dikutip oleh Agus Efendi (2005: 145), adalah kemampuan untuk memberikan gambargambar dan imagi-imagi, serta kemampuan dalam mentransformasikan dunia visual-spasial, termasuk di dalam kemampuan kemampuan menghasilkan imagi mental dan menciptakan representasi grafis, berpikir tiga dimensi, serta mencipta ulang dunia visual.

Oleh karena itu, menurut Gardner sebagaimana dikutip oleh Thomas Armstrong (2002: 10), inti dari kecerdasan ini adalah kepekaan mempersepsi (merasakan) dunia spasial-visual secara akurat dan mentransformasikan persepsi awal seseorang.

Selanjutnya, menurut Agus Efendi (2005: 145-146), Gardner menegaskan bahwa kecerdasan spasial mencakup sejumlah kapasitas yang kurang berhubungan; kemampuan mengenali contoh-contoh dari unsur yang sama; kemampuan mentransformasikan atau mengenali transformasi dari satu elemen ke elemen yang lain; kemampuan untuk menyulap pencitraan mental, kemudian mentransformasikan pencitraan tersebut; kemampuan memproduksi kesukaan grafis dari informasi spasial; dan seterusnya. Dengan begitu, menurut Agus Efendi (2005: 146), Gardner memaksudkan bahwa kecerdasan spasial adalah kecerdasan yang dapat digunakan untuk mengenali objek dan pemandangan di lingkungan aslinya.

Sementara itu, berkenaan dengan kecerdasan spasial pada anakanak sekolah, Paul Suparno (2008: 33) mengungkapkan bahwa anak yang memiliki kecerdasan spasial yang baik akan dengan mudah belajar ilmu ukur ruang. Selain itu, anak yang memiliki kecerdasan spasial, menurut Thomas Armstrong (2002: 28) juga memiliki ciri-ciri lain, antara lain mampu memberikan gambaran visual yang jelas ketika sedang memikirkan sesuatu, mudah membaca peta, grafik, dan diagram, menggambar sosok orang atau benda yang persis aslinya, senang melihat 
film, slide, atau foto, menikmati ketika melakukan teka-teki jigsaw, maze, atau kegiatan visual lain, sering melamun, membangun konstruksi tiga dimensi yang menarik, mencoret-coret di atas secarik kertas atau di buku tugas sekolah, dan lebih banyak memahami sesuatu melalui gambar daripada kata-kata ketika sedang membaca.

4. Kecerdasan Kinestetik-Badani (Bodily-Kinesthetic Intelegence)

Mengenai kecerdasan kinestetik badani ini, dalam bukunya Multiple Intelligences, Gardner (2003) mengemukakan sebuah ilustrasi. Dari ilustrasi tersebut dapat dipahami bahwa orang yang memiliki kecerdasan kinestetik-badani mampu memahami sesuatu yang berkaitan dengan gerakan badan sebelum dia memperoleh latihan secara formal, atau bisa memahami dan melakukan gerakan dengan tepat hanya dengan latihan yang relatif singkat.

Kecerdasan kinestetik-badani (tubuh), menurut Tony Buzan sebagaimana dikutip oleh Agus Efendi (2005: 152) merupakan kemampuan untuk memahami, mencintai dan memelihara tubuh, dan membuatnya berfungsi seefisien mungkin bagi orang yang bersangkutan. Dengan kata lain, kecerdasan tubuh adalah kecerdasan atletik dalam mengontrol tubuh seseorang dengan sangat cermat. Oleh karena itu, menurut Agus Efendi (2005: 152), Buzan menegaskan bahwa jika kita memiliki kecerdasan tubuh yang tinggi maka kita akan memahami hubungan antara otak dan tubuh, men sana in corpore sano, pikiran yang sehat terdapat dalam badan yang sehat dan sebaliknya, badan yang sehat berada dalam pikiran yang sehat.

Sementara itu, Howard Gardner sebagaimana dikutip oleh Paul Suparno (2008: 34), memaknai kecerdasan kinestetik-badani sebagai kemampuan menggunakan tubuh atau gerak tubuh untuk mengekspresikan gagasan dan perasaan. Dalam hal ini termasuk keterampilan koordinasi dan fleksibilitas tubuh. Berkenaan dengan hal ini, May Lwin, dkk. (2008: 168-170) menyatakan bahwa kemampuan ini pada umumnya dirujuk sebagai keterampilan psikomotor yang menggabungkan 
inter-prestasi mental dengan tanggapan fisik. Kemampuan ini juga merujuk pada kemampuan untuk mengkoordinasikan bagian-bagian tubuh seseorang dengan otak supaya berfungsi secara sinkron untuk mencapai tujuan fisik.

Selanjutnya, orang yang memiliki kecerdasan ini menurut Paul Suparno (2008: 35), akan dengan mudah dapat mengungkapkan diri dengan gerak tubuh mereka. Apa yang mereka pikirkan dan rasakan, akan dengan mudah diekspresikan dengan gerak tubuh atau ekspresi tubuh. Selain itu, mereka juga dengan mudah dapat memainkan mimik, drama, dan peran. Berbagai keterampilan fisik yang ditangani dan dimanipulasi oleh orang-orang yang memiliki kecerdasan ini, menurut Adi W. Gunawan (2006: 240) biasanya diiringi oleh keterampilan dalam koordinasi, keseimbangan, daya tahan, kekuatan, kelenturan, dan kecepatan. Melalui keterampilan-keterampilan tersebut, maka menurut Tadkiroatun Musrifah (2008: 51-52), gerakan-gerakan yang mereka perlihatkan akan terlihat seimbang, luwes, dan cekatan.

Anak-anak dengan kecerdasan ini, menurut Thomas Armstrong (2002: 29), bisa berkomunikasi dengan sangat efektif melalui gerakan dan bentuk-bentuk bahasa tubuh yang lain. Oleh karena itu, mereka butuh kesempatan untuk belajar dengan bergerak atau memperagakan sesuatu.

Selain mempunyai ciri-ciri di atas, anak yang memiliki kecerdasan kinestetik-badani ini menurut Thomas Armstrong (2002: 30), biasanya berprestasi dalam olahraga kompetitif di sekolah atau di lingkungan pemukiman, bergerak-gerak ketika sedang duduk, terlibat dalam kegiatan fisik seperti berenang, bersepeda, hiking, atau bermain skateboard, perlu menyentuh sesuatu yang ingin dipelajari, menikmati melompat, lari, gulat, atau kegiatan lain yang serupa, memperlihatkan keterampilan dalam bidang kerajinan, pandai menirukan gerakan, kebiasaan, atau perilaku orang lain, atau sangat suka membongkar berbagai benda dan kemudian menyusunnya lagi. Dengan kemampuan yang besar dalam koordinasi gerak tubuh itu pula, maka sekolah hendaknya menyediakan peluang 
sebesar-besarnya bagi anak untuk belajar sesuai dengan keterampilan mereka.

5. Kecerdasan Musikal (Musical Intelligence)

Kecerdasan musik, menurut Gardner sebagaimana dikutip oleh Paul Suparno (2008: 36), adalah kemampuan untuk mengembangkan, mengekspresikan, dan menikmati bentuk-bentuk musik dan suara. Selain itu, menurut Adi W. Gunawan (2006: 235), kecerdasan musik juga meliputi kemampuan untuk mengamati, membedakan, mengarang, dan membentuk bentuk-bentuk musik, kepekaan terhadap ritme, melodi, dan timbre dari musik yang didengar.

Kecerdasan ini, menurut May Lwin, dkk. (2008: 137) merupakan kecerdasan pertama yang harus dikembangkan dari sudut pandang neurologis. Bahkan dikatakan bahwa dari semua bentuk kecerdasan, musik dan irama pada otak memiliki pengaruh yang terbesar terhadap kesadaran seseorang. Kekuatan musik, irama, suara, dan getaran mampu menggeser pikiran, memberi ilham pengabdian relijius, meningkatkan kebanggan nasional, dan mengungkapkan kasih atau rasa kehilangan dan duka yang dalam untuk orang lain.

Selanjutnya, ditinjau dari sudut perkembangan, kecerdasan ini pada dasarnya merupakan kecerdasan yang paling awal mengalami perkembangan pada manusia, bahkan sudah tumbuh sejak masih balita (Gardner 2003). Namun demikian, Julia Jasmine (2007: 24) menyatakan bahwa kecerdasan ini merupakan kecerdasan yang paling sedikit dipahami dan didukung di lingkungan akademik. Kesimpulan ini didukung oleh realitas bahwa anak-anak yang bersenandung, bersiul, dan bernyanyi di sekolah seringkali dipandang melakukan tindakan yang tidak patut dan mengganggu ketenangan kelas. Padahal menurut Julia Jasmine (2007), anak-anak yang dicap sebagai pembuat masalah ini sedang menunjukkan perilaku yang mencerminkan kecerdasan musikalnya. 


\section{Kecerdasan Interpersonal (Interpersonal Intelligence)}

Kecerdasan interpersonal menurut Gardner, sebagaimana dikutip oleh Paul Suparno (2008: 39) adalah kemampuan untuk mengerti dan menjadi peka terhadap perasaan, intensi, motivasi, watak, dan temperamen orang lain, kepekaan akan ekspresi wajah, suara, serta isyarat orang lain. Selain kemampuan memahami dan memperkirakan perasaan, temperamen, suasana hati, maksud, dan keinginan orang lain, kecerdasan interpersonal ini menurut May Lwin, dkk. (2008: 197) juga menyangkut kemampuan untuk memberikan tanggapan secara layak terhadap kondisi orang lain. Melalui kecerdasan ini pula, menurut Adi W. Gunawan (2006: 237), seseorang mampu mengamati perubahan kecil yang terjadi pada mood, perilaku, motivasi, dan perhatian orang lain. Inilah kecerdasan yang dimiliki oleh orang-orang ekstrovet (Julia Jasmine 2007: 27). Jadi, secara umum kecerdasan interpersonal berkaitan dengan kemampuan seseorang untuk menjalin relasi dan komunikasi dengan berbagai orang. Kecerdasan ini menurut Paul Suparno (2008: 39) banyak dimiliki oleh para komunikator, fasilitator, dan penggerak massa.

Orang yang memiliki kecerdasan interpersonal yang baik, menurut Paul Suparno (2008: 39), biasanya sangat mudah bekerja sama dan berkomunikasi dengan orang lain. Hubungan dengan orang lain bagi mereka yang mempunyai kecerdasan ini sangat menyenangkan dan sepertinya keluar begitu saja secara otomatis. Mereka dengan mudah mengenali dan membedakan perasaan serta apa yang dialami teman dan orang lain, bahkan mereka juga mudah menunjukkan sikap empati terhadap orang lain yang mengalami masalah.

7. Kecerdasan Intrapersonal (Intrapersonal Intelligence)

Kecerdasan intrapersonal menurut Paul Suparno (2008: 41) adalah kemampuan yang berkaitan dengan pengetahuan akan diri sendiri dan kemampuan untuk bertindak secara adaptif berdasar pengenalan diri itu. Termasuk dalam kecerdasan ini adalah kemampuan berefleksi dan keseimbangan diri, memiliki kesadaran tinggi akan gagasan-gagasannya, 
mempunyai kemampuan untuk mengambil keputusan pribadi, sadar akan tujuan hidupnya, bisa mengatur perasaan serta emosi dirinya sendiri. Orang yang memiliki kecerdasan yang tinggi dalam bidang ini adalah orang yang mampu menjadi dirinya sendiri yang sejati.

Diri sejati itu sendiri, menurut James Masterson sebagaimana dikutip oleh Thomas Armstrong (2002: 118-119), mempunyai sejumlah komponen, antara lain:

a. Kemampuan untuk mengalami berbagai perasaan secara mendalam dengan gairah, semangat, dan spontanitas.

b. Kemampuan bersikap tegas.

c. Pengakuan terhadap harga diri

d. Kemampuan untuk meredakan perasaan sakit pada diri sendiri.

e. Mempunyai segala sesuatu yang diperlukan untuk mempertahankan niat dalam pekerjaan maupun relasi.

f. Kemampuan untuk berkreasi dan berhubungan secara dekat.

g. Kemampuan untuk menyendiri.

Kecerdasan intrapersonal ini, menurut Julia Jasmine (2007: 27-28) biasanya dimiliki oleh orang-orang introvert. Kecerdasan interpersonal dan intrapersonal merupakan bagian yang tak terpisahkan dari teori kecerdasan emosional. Adapun model-model kecerdasan emosional tersebut yaitu: mengenal emosi seseorang; mengelola emosi; memotivasi diri; mengenali emosi-emosi orang lain; dan menangani hubungan (Barbara Prashnig 2007: 235-237).

8. Kecerdasan Naturalis/Lingkungan (Naturalist Intelligence)

Kecerdasan naturalis, menurut Howard Gardner sebagaimana dikutip oleh Paul Suparno (2008: 42), adalah kemampuan seseorang untuk dapat mengerti flora dan fauna dengan baik, dapat membuat distingsi konsekuensial lain dalam alam natural; kemampuan untuk memahami dan menikmati alam serta menggunakan kemampuan tersebut secara produktif dalam bertani, berburu, dan mengembangkan pengetahuan alam lainnya. 
Menurut Howard Gardner, sebagaimana dikutip oleh Thomas Armstrong (2002: 215), kecerdasan naturalis ini tidak hanya bisa berkembang pada orang-orang yang dekat pada flora dan fauna saja, namun orang yang jauh dari flora dan fauna, seperti orang-orang yang hidup di kota, juga bisa mengembangkan kecerdasan naturalisnya, karena kecerdasan naturalis itu tidak sekedar kemampuan untuk memahami flora dan fauna saja tetapi bisa berupa kemampuan untuk membedakan jenis benda-benda yang ada di kota, seperti jenis sampul CD, sepatu karet, atau mobil.

Orang yang memiliki kecerdasan naturalis yang tinggi, menurut Paul Suparno (2008: 42), mampu hidup di luar rumah, dapat berteman dan berhubungan baik dengan alam, mudah membuat identifikasi dan klasifikasi tanaman dan binatang. Orang ini mempunyai kemampuan untuk mengenal sifat dan tingkah laku binatang, mencintai lingkungan, dan tidak suka merusak lingkungan hidup.

\section{Kecerdasan Eksistensial (Existential Intelligence)}

Kecerdasan eksistensial, menurut Howard Gardner sebagaimana dikutip oleh Thomas Armstrong (2004: 250), pada dasarnya adalah minat pada masalah-masalah pokok kehidupan. Kecerdasan ini mencakup kemampuan menempatkan diri dalam hubungan dengan jangkauan kosmos yang terjauh (yang tidak terhingga besarnya dan tidak terhingga kecilnya) dan kemampuan lain yang terkait, yakni menempatkan diri dalam hubungan dengan berbagai aspek eksistensial manusia, misalnya makna hidup, arti kematian, nasib dunia fisik dan psikologis, serta pengalaman mendalam seperti cinta pada sesama atau keterlibatan total dalam karya seni.

Sama seperti kecerdasan lainnya, menurut Thomas Armstrong sebagaimana dikutip oleh Tadzkiroatun Musfiroh (2008: 61), kecerdasan ini mulai muncul pada awal masa kanak-kanak. Karena anakanak belum mempunyai penyaring kebudayaan seperti orang dewasa, mereka selalu dapat menerima rahasia kehidupan dan secara terus 
menerus mengajukan pertanyaan besar yang sulit dijawab oleh orang dewasa di sekitarnya. Hal ini, menurut Tadzkiroatun Musfiroh (2008: 61), biasanya ada pada anak-anak yang memiliki kecerdasan eksistensial yang tinggi bahkan mereka juga cenderung memiliki kesadaran akan hakikat sesuatu. Mereka banyak mengajukan pertanyaan mengenai berbagai hal yang mungkin tidak terpikirkan oleh anak lain yang sebaya, contohnya pertanyaan-pertanyaan anak mengenai apa yang terjadi ketika orang meninggal dunia, mengapa ada orang jahat, dan mengapa harus sembahyang.

Walaupun penerapannya mungkin sulit, namun kecerdasan ini menurut Gardner sebagaimana diungkapkan oleh Thomas Armstrong (2004: 251-252), bisa dikategorikan sebagai bagian dari kecerdasan majemuk karena memenuhi sebagian besar kriteria kecerdasan majemuk. Adapun kriteria-kriteria yang dipenuhi oleh kecerdasan ini antara lain: nilai kultural, sejarah perkembangan, sistem simbol, individu-individu luar biasa (savant), kajian psikometrik, plausibilitas evolusioner dan penelitian otak.

Oleh karena kecerdasan eksistensial memenuhi sebagain besar kriteria kecerdasan majemuk, maka Howard Gardner menjadikan kecerdasan ini sebagai salah satu bagian kecerdasan majemuk. Dengan demikian, kecerdasan majemuk terdiri dari sembilan macam kecerdasan, yaitu kecerdasan linguistik, kecerdasan matematis logis, kecerdasan ruang-spasial, kecerdasan kinestetik-badani, kecerdasan musical, kecerdasan interpersonal, kecerdasan intrapersonal, kecerdasan naturalis, dan kecerdasan eksistensial.

\section{Kesimpulan}

Berdasarkan penjelasan dan uraian singkat di atas, maka dapat disimpulkan bahwa teori kecerdasan majemuk merupakan suatu teori yang digagas oleh Howard Gardner untuk mengungkapkan banyaknya (kemajemukan) kecerdasan yang dimiliki oleh setiap individu. Sedikitnya ada empat hal yang melatarbelakangi munculnya teori kecerdasan majemuk yaitu: ide mengenai 
kecerdasan majemuk, pandangan awal mengenai kecerdasan, fondasi biologis kecerdasan, apa itu kecerdasan.

Selanjutnya menurut Howard Gardner, minimal ada sembilan kecerdasan, yaitu:

a. Kecerdasan linguistik adalah kemampuan untuk menggunakan dan mengolah kata-kata secara efektif, baik secara oral maupun tertulis.

b. Kecerdasan matematis-logis adalah kemampuan untuk menangani bilangan dan perhitungan, pola dan pemikiran logis dan ilmiah.

c. Kecerdasan ruang (spasial) adalah kemampuan untuk menangkap dunia ruang-visual secara tepat.

d. Kecerdasan musikal (irama musik) adalah kemampuan untuk mengembangkan, mengekspresikan, dan menikmati bentuk-bentuk musik dan suara.

e. Kecerdasan kinestetik-badani adalah kemampuan menggunakan tubuh atau gerak tubuh untuk mengekspresikan gagasan atau perasaan.

f. Kecerdasan antarpribadi (interpersonal) adalah kemampuan untuk mengerti dan peka terhadap perasaan, intensi, motivasi, watak, dan temperamen orang lain.

g. Kecerdasan intrapribadi (intrapersonal) adalah kemampuan yang berkaitan dengan pengetahuan akan diri sendiri dan kemampuan untuk bertindak secara adaptatif berdasar pengenalan diri itu.

h. Kecerdasan naturalis (lingkungan) adalah kemampuan untuk mengerti flora dan fauna dengan baik, dapat membuat distingsi konsekuensial lain dalam alam natural; kemampuan untuk memahami dan menikmati alam; dan menggunakan kemampuan tersebut secara produktif.

i. Kecerdasan eksistensial adalah kepekaan atau kemampuan untuk menjawab persoalan-persoalan terdalam eksistensi manusia.

Kesembilan kecerdasan tersebut perlu dikembangkan secara maksimal dan sejak usia dini, agar bermanfaat bagi individu yang bersangkutan. Hal ini karena pada usia tersebut, manusia mengalami perkembangan yang sangat pesat dan apa-apa yang dipelajari di masa tersebut menjadi pijakan bagi masamasa selanjutnya. 


\section{DAFTAR PUSTAKA}

Armstrong, Thomas, 7 Kinds of Smart: Menemukan dan Meningkatkan Kecerdasan Anda Berdasarkan Teori Multiple Intelligences, Jakarta: Gramedia Pustaka Utama, 2002.

Sekolah Para Juara: Menerapkan Multiple Intelligences di Dunia Pendidikan, Bandung: Kaifa, 2004.

Setiap Anak Cerdas: Panduan Membantu Anak Belajar dengan Memanfaatkan Multiple Intelligence-nya, Jakarta: Gramedia Pustaka Utama, 2005.

Efendi, Agus, Revolusi Kecerdasan Abad 21: Kritik MI, EI, SQ, AQ, dan Successful Intelligence atas IQ, Bandung: Alfabeta, 2005.

Gardner, Howard, Frames of Mind, Intelligence Reframed: Multiple Intelligences for The $21^{\text {st }}$ Century, New York: Basic Books, 1973.

Intelligence Reframed: Multiple Intelligences for The 21 ${ }^{\text {st }}$ Century, New York: Basic Books, 1999.

Multiple Intelligences: Kecerdasan Majemuk, Teori dalam Praktek, terj. Alexander Sindoro, Batam: Interaksara, 2003.

Gunawan, Adi W., Genius Learning Strategy: Petunjuk Praktis untuk Menerapkan Accelerated learning, Jakarta: Gramedia Pustaka Utama, 2006.

Hoerr, Thomas R., Buku Kerja Multiple Intelligences, terj. Ary Nilandari, Bandung: Mizan Pustaka, 2007.

Jasmine, Julia, Panduan Praktis Mengajar Berbaris Multiple Intelligences, Bandung: Nuansa, 2007.

Lwin, May, dkk., How to Multiply Your Child's Intelligence: Cara Mengembangkan Berbagai Komponen Kecerdasan, terj. Christine Sujana, Yogyakarta: Indeks, 2008.

Mujib, Abdul dan Jusuf Mudzakir, Nuansa-Nuansa Psikologi Islam, Jakarta: RajaGrafindo Persada, 2002.

Mulkhan, Abdul Munir, Nalar Spiritual Pendidikan: Solusi Problem Filosofis Pendidikan Islam, Yogyakarta: Tiara Wacana Yogya, 2002.

Musrifah, Tadkiroatun, Cerdas Melalui Bermain: Cara Mengasah Multiple Intelligences Anak sejak Usia Dini, Jakarta: Grasin 
Naisaban, Ladislaus, Para Psikolog Terkemuka Dunia: Riwayat Hidup, Pokok Pikiran, dan Karya, Jakarta: Grasindo, 2004.

Suparno, Paul, Teori Inteligensi Ganda dan Aplikasinya di Sekolah: Cara Menerapkan Teori Multiple Intelligences Howard Gardner, Yogyakarta: Kanisius, 2008.

Prashnig, Barbara, The Power of Learning Styles: Memacu Anak Melejitkan Prestasi dengan Mengenali Gaya Belajarnya, terj. Nina Fauziah, Bandung: Kaifa, 2007. 